TARNOWSKIE STUDIA TEOLOGICZNE 35 (2016) NR 2, S. 153-162

http://dx.doi.org/10.15633/tst.2111

ks. Józef Młyński

UNIWERSYTET KARDYNAŁA STEFANA WYSZYŃSKIEGO W WARSZAWIE

\title{
Międzynarodowa konferencja naukowa Rodzina: miłość, małżeństwo, odpowiedzialność. Refleksja nad nauczaniem ks. prof. dr. hab. Jerzego Bajdy
}

(Warszawa, 14 listopada 2015 roku)

W sobotę 14 listopada 2015 roku na Uniwersytecie Kardynała Stefana Wyszyńskiego w Warszawie odbyła się Międzynarodowa konferencja naukowa pt. Rodzina: miłość, małżeństwo, odpowiedzialność. Refleksja nad nauczaniem ks. prof. dr. hab. Jerzego Bajdy. Organizatorami tego naukowego spotkania byli: Wydział Studiów nad Rodziną, Katedra Socjologii Małżeństwa i Rodziny Uniwersytetu Kardynała Stefana Wyszyńskiego w Warszawie oraz Wydział Teologiczny Uniwersytetu w Trnavie.

Konferencja rozpoczęła się mszą świętą, której przewodniczył JE ks. bp Andrzej Jeż, ordynariusz diecezji tarnowskiej. W homilii ksiądz biskup, przywołując z ikonografii postać św. Jerzego, wskazał, że „Ksiądz prof. Jerzy Bajda, mając takiego patrona, możemy powiedzieć, że komunikacją słowa doskonale potrafił walczyć ze złem. Potrafił precyzyjnie uderzać w istotę zła, w sposób kulturalny posługując się kodeksem rycerskim z Ewangelii, ale równocześnie w sposób zdecydowany idąc drogą prawdy".

Po celebracji mszy świętej na początku głos zabrał ks. prof. dr hab. Mieczysław Ozorowski (dziekan wsR UKsw Warszawa), który powitał wszystkich uczestników konferencji i skierował słowo wprowadzające, podkreślając niezwykłą prostotę i pokorę ks. prof. Jerzego Bajdy. W dalszej kolejności ponownie głos zabrał ks. bp Andrzej Jeż, ukazując postać ks. prof. Jerzego Bajdy, wyczulonego na antropologię codziennego bytowania. On nie tylko mówił o wartości i godności człowieka, ale potrafił realizować pełnię i autentyzm człowieczeństwa w swoim życiu. To było podstawą jego wielkiego autorytetu na płaszczyźnie akademickiej wśród studentów i pracowników naukowo-dydaktycznych. Jego piękne człowieczeństwo, jak zaznaczył ksiądz biskup, tworzyło w jego życiu harmonijną całość z kapłaństwem. 
Stąd 58 lat przeżytych w kapłaństwie nie było jakimś dodatkiem, lecz stanowiło integralną część życia, człowieczeństwa i pracy naukowej. Z kolei JM ks. prof. dr hab. Stanisław Dziekoński (rektor uksw) wyraził radość z podjętego tematu konferencji, uwypuklającego wartość małżeństwa i rodziny, których obrońcą i promotorem był ks. prof. Jerzy Bajda.

Przedpołudniowej sesji plenarnej przewodniczył ks. dr Józef Młyński (wsR-uKsw Warszawa). W tej części jako zaprezentowany został wykład dr Wandy Półtawskiej. Niestety, pani doktor z przyczyn niezależnych nie mogła osobiście uczestniczyć w konferencji, ale przesłała nagranie multimedialne, które zostało odsłuchane. Prelegentka w wykładzie pt. Rola św. Jana Pawła II w życiu Księdza Profesora Jerzego Bajdy podkreśliła wartość działalności księdza profesora i ukazała świadectwo jego życia. Stwierdziła bowiem: „Istnieje potrzeba opracowania dokładnej biografii księdza profesora. Natomiast moje przemówienie będzie rodzajem świadectwa współpracy z tym kapłanem, ponieważ ks. Jerzy Bajda jest jednym z niewielu księży, którym bardzo dużo zawdzięczam i który bardzo mi pomagał w całej mojej działalności zarówno lekarskiej, jak i duszpasterskiej. Zwróciłam się do niego, raczej zwróciłam uwagę na niego dzięki temu, że wręcz powiedział mi o nim ksiądz biskup Karol Wojtyła. Ksiądz biskup Wojtyła wrócił z soboru i zorganizował spotkanie teologów, którzy mieli opracować materiał dla Pawła vi na temat etyki małżeńskiej. Do tych teologów zaproszonych przez księdza biskupa należał ks. Jerzy Bajda”. W dalszej kolejności ks. dr Ryszard Banach (wsD Tarnów, wTST UPJPII Kraków), przedstawiał życiorys ks. Jerzego Bajdy, dokonując szczegółowego opisu, od najmłodszych lat. Podkreślał, jak ważną rolę w życiu księdza profesora zajmowała Maryja. Ks. Bajda do kapłaństwa przygotowywał się bardzo odpowiedzialnie. Rozpoczął naukę w Seminarium Duchownym w Tarnowie, ponieważ uważał, że musi zrobić coś dla Polski swojej ojczyzny - a jego zdaniem tym „czymś” było właśnie kapłaństwo. Kapłaństwo określał jako współdziałanie z Bogiem w ratowaniu świata. Prelegent opisał życie ks. Bajdy, uwzględniając całą jego działalność dla Kościoła i rodziny oraz wszelkie osiągnięcia.

Ks. dr Krzysztof Wolski (wsR-UKsw Warszawa) jako kolejny prelegent wygłosił referat pt. Ks. prof. Jerzy Bajda jako profesor $w$ środowisku naukowym. Prodziekan Wydziału Studiów nad Rodziną przedstawił postać księdza profesora $\mathrm{w}$ środowisku naukowym. W roku 1972 rozpoczął pracę naukową oraz dydaktyczną w Akademii Teologii Katolickiej w Warszawie. Rok później został adiunktem tejże akademii. W 1993 roku został uzyskał 
tytuł profesora Akademii Teologii Katolickiej. Cztery lata później został kierownikiem katedry Teologii Moralnej Małżeństwa i Rodziny w Instytucie Studiów nad Rodziną Uniwersytetu Kardynała Stefana Wyszyńskiego. Ks. prof. Jerzy Bajda był także wybitnym członkiem rady naukowej Instytutu Jana Pawła II na Katolickim Uniwersytecie Lubelskim.

Kolejnymi gośćmi byli państwo mgr Mirosława i dr Paweł Kwasowie. Tematem ich wystąpienia było środowisko rodzinne ks. prof. Bajdy. Sielankę dzieciństwa Jerzego Bajdy przerwał wybuch II wojny światowej, jednak matka księdza zachęcała dzieci do modlitwy, do odmawiania codziennego różańca, aby Maryja czuwała nad nimi w tym czasie. Ojciec księdza profesora był urzędnikiem w Starostwie Powiatowym. Siostra Jerzego Bajdy, Krystyna, także wybrała drogę służby Bożej. Ksiądz profesor - we wspomnieniu prelegentów - był osobą wrażliwą na innych ludzi, nie dbał o siebie, lecz o innych. Uwielbiał spacerować w lesie. Zawsze z szacunkiem odnosił się do każdego człowieka, a w szczególności do dzieci.

Modlitwa i odpowiedzialność w życiu i nauczaniu ks. prof. Jerzego Bajdy to temat, który przedstawili kolejni prelegenci - mgr Adam i mgr Wanda Ekielscy. W miejscu, gdzie wychowywał się ksiądz profesor, znajdował się kościół św. Mikołaja - Sanktuarium Matki Bożej Różańcowej. Największą atrakcją dla małego Jerzego Bajdy były msze święte w kaplicy. Był przekonany, że Matka Boża wszystkich wysłuchuje i obdarza opieką. Do kapłaństwa przygotowywał się bardzo dokładnie i odpowiedzialnie. Modlił się na różańcu o światło życiowej drogi oraz dobry wybór. Wszelkie wątpliwości rozwiał spowiednik. Ks. prof. Jerzy Bajda uważał, że musi zrobić coś dla ojczyzny, dla Polski, i jego zdaniem było to właśnie kapłaństwo - współdziałanie $\mathrm{z}$ Bogiem w ratowaniu świata.

Kolejne wystąpienie dotyczyło wywiadu przeprowadzonego z księdzem profesorem Jerzym Bajdą pt. Mistrz i uczeń. Wywiad ostatni przed śmiercia zaprezentowanego przez ks. dr. Władysława Szewczyka (wsD Tarnów, wsR uksw Warszawa) oraz ks. dr. Józefa Młyńskiego (wsR UKsw Warszawa).

Z kolei ks. prof. dr hab. Ladislav Csontos (prorektor Uniwersytetu Trnawskiego, w Tratysława) przedłożył wykład na temat: „Rola odpustenia v rodine" (Rola przebaczenia w rodzinie) i podkreślił, że miłość i krzyż to dwie strony jednej monety. Otwierając się na miłość, człowiek otwiera się całkowicie i traci ochronę (jak żołnierz zbroję) - jest szczególnie narażony na zranienia. Bardzo łatwo jest ranić i zostać zranionym w miłości. W codzienności może zranić słowo, spojrzenie, milczenie, na które w małżeństwie narażamy 
się codziennie przez całe życie. Małżeństwo katolickie to naśladowanie drogi Chrystusa - „Jeśli kto chce iść za Mną, niech się zaprze samego siebie, niech co dnia bierze krzyż swój i niech Mnie naśladuje” (Łk 9, 23). Bez krzyża nie może być łaski i należy go przyjąć jako drogę wzrostu, poświęcać się jeden dla drugiego (Ef 5, 25-35). Chrystus miłował tym, że się darował. Jeden człowiek jest darem dla drugiego, a gdy kocham, to daję siebie i to, co mam. Istotnym zatem czynnikiem funkcjonowania i harmonii w rodzinie jest przebaczenie.

Ks. prof. zw. dr hab. Władysław Majkowski (AP w Częstochowie) przedłożył referat pt. Dylematy polskich młodych małżeństw. Jednym z dylematów współczesnych polskich małżeństw jest posiadanie potomstwa. Małżonkowie zastanawiają się, czy w ogóle chcą mieć dzieci, kiedy, czy są w stanie te dzieci utrzymać. Szczególnie w obszarach wielkomiejskich ludzie nastawieni są na karierę zawodową, egoistycznie myśląc tylko o sobie. Mimo iż „rodzina” cieszy się wielkim prestiżem w opinii Polaków, to rzeczywistość odbiega od składanych deklaracji na temat rodziny. Młodzi ludzie stają przed licznymi dylematami. Pierwszy z nich to: czy żyć w związku, czy pozostać „singlem”. Jeżeli nawet decydują się na pierwsze rozwiązanie, to rodzi się kolejny problem: czy sformalizować związek, czy żyć w kohabitacji. Coraz częściej młodzi ludzie decydują się pozostać formalnie wolnymi osobami, gdyż boją się odpowiedzialności, jaka wiąże się z zawarciem związku małżeńskiego.

W popołudniowej części konferencji zawarto trzy panele: refleksja nad nauczaniem ks. prof. Jerzego Bajdy; rodzina - wspólnotą osób; małżeństwo i rodzina - dobro wspólne. W panelu pierwszym, którego moderatorem był ks. prof. zw. dr hab. Władysław Majkowski spośród wielu prelegentów jako pierwszy referat na temat Ks. prof. Jerzy Bajda - teolog moralista, obrońca obiektywnej prawdy o rodzinie wygłosił ks. prof. dr hab. Ireneusz Mroczkowski (wSR UKSW Warszawa). Prelegent przedstawił koncepcję teologii moralnej ks. prof. Jerzy Bajdy oraz jego stanowisko na tle dyskusji posoborowych. Główne punkty teologii powołania ks. prof. Bajdy to: człowiek stworzony na obraz i podobieństwo Boga tworzy relację Bóg - człowiek na płaszczyźnie sakramentu; powołanie chrześcijańskie stanowi podstawę rozwoju człowieka; rozumienie sakramentu jako powołanie. Zostało poruszone także zagadnienie równości mężczyzny i kobiety w kontekście małżeństwa i rodziny. Ks. prof. Mroczkowski omówił kilka kwestii z encykliki Humanae vitae. Słuchaczom zostały przybliżone dwie pozycje naukowe ks. prof. Jerzy 
Bajdy: Rodzina miejscem Boga i człowieka oraz Powołanie chrześcijańskie jako zasada teologii moralnej. Na koniec wystąpienia została przedstawiona kwestia związków niesakramentalnych, duszpasterskie towarzyszenie osobom w związkach niesakramentalnych, elementy prawdy i uświęcenia.

Kolejno wystąpiła dr hab. Maria Ryś, prof. uksw (wfch uksw Warszawa) $\mathrm{z}$ tematem: Zadania rodziny we współczesnym świecie $w$ świetle nauczania ks. prof. Jerzy Bajdy. Prelegentka przedstawiła ks. prof. Jerzy Bajdę jako sługę rodzin. Według niej rodzina powinna przemawiać jednym głosem modlitwą. Rodzina jako wspólnota życia to bogatsze społeczeństwo oraz szkoła mądrości życiowej, cnót i wartości. Rodzina jako komórka społeczna to także patriotyzm, bo „tylko rodzina daje człowiekowi korzenie i skrzydła”. Prof. Ryś wspominała, że ks. prof. Jerzy Bajda zawsze i we wszystkim szukał nawet najmniejszych śladów wskazujących na Pana Boga, często nawiązywał do Listu do Rodzin Jana Pawła II. Zadania rodziny według ks. prof. Jerzy Bajdy, które wymieniła podczas wystąpienia prof. Ryś, to odkrycie swego powołania, ponieważ rodzina jest dziełem Bożym - powołaniem: powołanie do małżeństwa to powołanie tylko mężczyzny i kobiety tylko do małżeństwa sakramentalnego; powołanie rodziny do życia, otwartość na życie, przyjmowanie daru życia. Kończąc swoje wystąpienie, prof. Ryś podkreśliła, że każda rodzina powinna mieć za wzór Świętą Rodzinę. W koncept dalszej analizy rodziny wpisała się dr Bożena Bassa (wsR uksw Warszawa), która referując temat Rodzina miejscem szczególnej odpowiedzialności za dar życia w nauczaniu ks. prof. Jerzy Bajdy, stwierdziła, iż ksiądz profesor wyjaśniał wszelkie aspekty rodziny i rodzicielstwa w świetle Objawienia. Bóg jako Stwórca życia ludzkiego obdarza ludzi rodzicielstwem. Człowiek nie jest panem ani źródłem życia, jest natomiast wykonawcą planu Boga. Rodzicielstwo stanowi misję od Boga, przez co tworzy się szczególna więź z Panem Bogiem. Prelegentka przedstawiła 9 punktów Listu do Rodzin, w którym mowa o genealogii, osobistym zaangażowaniu i obecności Boga w ludzkim rodzicielstwie. Szczególna odpowiedzialność rodzicielstwa wynika z misji i powołania oraz daru życia. Miłość małżeńska nie może zrezygnować z płodności. Podstawowym prawem dziecka jest umieszczenie go w centrum komunii osób. Została poruszona także kwestia antykoncepcji, cywilizacji śmierci.

Ostatnim prelegentem tej części panelu był ks. dr Andrzej Pryba (wT UAM Poznań), który ukazał Etyczno-charyzmatyczny wymiar powołania małżeńsko-rodzinnego w nauczaniu ks. prof. Jerzy Bajdy. Zdaniem referenta 
powołanie do małżeństwa jest jedną z najważniejszych kwestii. To, czym jest rodzina, zależy od tego, jak Bóg to zaplanował, nie od tego, jak widzi to np. psychologia. Bóg powołuje człowieka do miłości. Dar to rzeczywistość, jaką otrzymujemy od Boga. Byt ludzki jest ukonstytuowany na obraz i podobieństwo Boga. Stworzenie człowieka jest od początku skierowane ku wspólnocie - komunii - to cecha planu stwórczego. Człowiek nie powinien stawać się niewolnikiem świata doczesnego, lecz darem dla Stwórcy.

Drugi panel, któremu przewodniczył ks. dr Władysław Szewczyk, rozpoczął się wystąpieniem dr. Tadeusza Wójcika, który poruszył tematykę cudu natury w przyrodzie. Prelegent przedstawił ten temat w aspekcie zasobów energii jądrowej. Zdaniem dr Wójcika do form energii zaliczamy ruch mechaniczny, ciepło, światło oraz energię jądrową. W tym ujęciu najnowsza technologia polega na wydobywaniu energii z plazmy powstałej w wyniku wybuchu energii jądrowej, która stanowi podstawową formę energii. Prelegent w dalszej części swojego wystąpienia zwrócił uwagę na zagrożenia cywilizacyjne, do których zaliczył eksplozję demograficzną, wyczerpywanie się zasobów światła oraz zanieczyszczenie środowiska. Reasumując, dr Wójcik podkreślił, że człowiek jest mikrokosmosem i jest zależny od wszechświata. Swoją wypowiedź podsumował myślą filozoficzną Kanta: „Dwie rzeczy napełniają mnie największym zachwytem: niebo gwiaździste nade mną i prawo moralne we mnie".

Drugi temat dotyczył cudu natury w odniesieniu do organizmu ludzkiego. To zagadnienie przedstawiła dr Elżbieta Wójcik, która nadmieniła, że ciało ludzkie zbudowane $\mathrm{z}$ materii, należy do świata przyrody. Według prelegentki istotnym czynnikiem, który sprawia, że człowiek przekracza tę przyrodę, jest posiadanie władzy duchowej, utożsamianej z rozumem i wolną wolą. Dlatego też do samodzielnego istnienia człowieka potrzebny jest rozum. Dr Wójcik podkreśliła, że siedzibą ludzkiej świadomości w organizmie człowieka jest mózg, który kontroluje ciało i odpowiada za rozumność. W mózgu znajdują się połączenia neuronowe i neuroprzekaźniki, dzięki którym w przeciągu mikrosekund wysyłane są sygnały do innych części ciała. Prelegentka, powołując się na badania naukowe, zwróciła uwagę na fakt, że bystrość mózgu zależy nie od ilości neuronów, ale od ilości połączeń w mózgu. Podsumowując swoje wystąpienie, referentka zauważyła, że ludzki mózg stanowi dla nas nadal nieodkrytą tajemnicę. Pomimo to, jesteśmy w stanie zwiększyć efektywność pracy naszego mózgu poprzez aktywność fizyczną, zbilansowaną dietę oraz ćwiczenia poprawiające sprawność naszego umysłu. 
Kolejny temat poruszany na konferencji był poświęcony rodzinie, małżeństwu, miłości i odpowiedzialności w kontekście nauczania ks. kard. Stefana Wyszyńskiego. Prelegent ks. dr hab. Zdzisław Struzik (wSR uksw Warszawa) podkreślił, że miłość małżeńska jako miłość rodzicielska pochodzi od Stworzyciela. Godność małżeńska ma swoje źródło w Bogu, jako dar dla małżonków. Dzięki takiemu spojrzeniu łatwiej jest człowiekowi zrozumieć miłość, która daje i służy. W tym względzie współpraca $z$ Bogiem jest niezbędna. Małżeństwo sakramentalne jest mieszkaniem Boga - nie jest samo, ale tworzy Kościół, jest we wspólnocie.

Związek między etyką a socjologią, ukazany na przykładzie teorii uczestnictwa Karola Wojtyły to kolejne zagadnienie przedstawione przez mgr Teresę Mazan (wsR uksw Warszawa). Prelegentka wykazała związek socjologii z etyką oraz jej odniesienie do badań empirycznych. Związek ten jest możliwy, o ile te dwie dziedziny nauki posiadają wspólne cele. Karol Wojtyła postrzegał socjologię jako dobro służące rozwojowi człowieka i społeczeństwa.

Kolejny prelegent, dr Andrzej Mazan (wsR uksw Warszawa) przybliżył temat wychowania rodzinnego w odniesieniu do tekstów ks. prof. Jerzego Bajdy. Podkreślił, że małżeństwo jest stworzone przez Boga nie przez przypadek, ale po to, by móc przyjąć dar Boży, jakim jest dziecko. Celem przyjęcia tego daru jest zapewnienie mu godnych warunków życia. Stąd też wynika prawo małżonków do wychowania. Małżeństwo sakramentalne, czyli takie, które ma swój początek w Bogu, tworzy moc wychowawczą dla rodziny. Wychowanie i kształtowanie sumienia człowieka jest niejako misją rodziny. Małżonkowie muszą jednak pamiętać, że nie są w tej misji samotni powinni szukać oparcia i wzorować się na osobie Jezusa Chrystusa.

Ostatnim zagadnieniem poruszanym na konferencji był temat wychowania seksualnego, przedstawiony przez dr. hab. Marka Czachorowskiego (wSR uksw Warszawa). Prelegent odniósł się do klasycznej definicji wychowania, rozumianej jako formacja sprawności moralnych. Zaznaczył, że problemem współczesnej pedagogiki jest oderwanie się od klasycznej filozofii i cnót moralnych. Stąd biorą się problemy moralne współczesnego człowieka, takie jak np. problem z definicją słowa „rodzina”, na co mogą wskazywać chociażby przykłady związków jednopłciowych. Zamęt widoczny $\mathrm{u}$ dorosłych w sferze seksualnej niewątpliwie przekłada się na funkcjonowanie dzieci i młodzieży w społeczeństwie. Dzieci nie mają odpowiedniego przykładu w kwestiach związanych z wychowaniem seksualnym. Referent 
swoje wystąpienie podsumował stwierdzeniem, że dopóki pedagogika nie wróci do związku z klasyczną filozofią, dopóty nie będzie mowy o szacunku dla człowieka.

Ostatnim prelegentem tego panelu był ks. dr Roman Gawlik (Austria), który omówił temat: Prawda o małżeństwie i rodzinie w środowisku Górnej Austrii. Jego wykład obejmował takie kwestie, jak: wartość tradycyjnego małżeństwa i rodziny, praktyki religijne, kryzysy małżeńskie, przygotowane do małżeństwa oraz duszpasterskie próby odnowienia instytucji małżeństwa i rodziny w Austrii. W tym kontekście mając świadomość odpowiedzialności za przyszłe pokolenia, w czasach zeświecczenia i laicyzacji codziennego życia, w czasach, gdy związek małżeński narażony jest na wiele prób i przeciwności, powinniśmy w jasny sposób przypominać pragnącym zawrzeć sakramentalny związek małżeński o jego szczególnym znaczeniu dla związku dwojga ludzi i ich potomstwa.

Panel trzeci moderowany przez ks. prof. dr. hab. Ladislava Csontosa rozpoczął wykład ks. prof. hab. Wojciecha Necela (wPK UKsw Warszawa) pt. Małżeńskie przymierze za zrządzeniem Bożym. Na początku dokonał wprowadzenia, przypominając o tym, że małżonkowie są jakby konsekrowani. Chrzest jest podstawową konsekracją, która nadaje status osobie, a konsekrującym jest sam Bóg. Celem małżeństwa jest wzajemne uświęcenie i wychowanie dzieci w taki sposób, aby kiedyś wszyscy spotkali się ze sobą w wieczności. Takie małżeństwo powstaje za zgodą stron i za zrządzeniem Bożym. Natomiast ks. dr hab. Andrzej Żuk (kU Eischstaett-Ingolstadt Niemcy), podejmując temat pt. Pięć ołtarzy małżeńskiej i rodzinnej wspólnoty: innowacyjny model duchowości, zwrócił uwagę na wartość wspólnoty małżeńsko-rodzinnej, podkreślając potrzebę duchowości w rodzinie. Duchowość ta, jak sam określił, powinna być „innowacyjna”. Kontynuacją wystąpienia poprzedniego prelegenta był referat przedłożony przez dr Urszulę Bejmę (wnHiS uKsw Warszawa). Prelegentka zwróciła uwagę na pewien dylemat, jaki rozgrywa się w każdym człowieku: kim chce być, jaki chce mieć status społeczny. Na początku człowiek potrzebuje rodziców i rodziny, musi mieć wokół siebie wielu ludzi. Rodzina stanowi dla człowieka istotną wartość w każdym czasie i w każdej epoce i jest fundamentem zastępowalności pokoleniowej. Przynajmniej takie przekonanie dominuje wśród większości Polaków. Niestety współczesny język bardzo często eliminuje z języka pojęcia: mąż, żona, rodzina, zastępując je partnerstwem. Dlatego tak ważne jest właściwe przygotowanie ludzi młodych do małżeństwa. Konieczne jest 
przygotowanie bliższe do rodzinnych postaw, pogłębianie wiedzy na temat psychiki kobiety i mężczyzny. Natomiast dr Dorota Gizicka (IS Kul Lublin) podjęła temat Kohabitacja przedmałżeńska - wzrost odpowiedzialności czy ucieczka przed odpowiedzialnością. Stwierdziła, że dzisiaj słowo „konkubinat" wzbudza odczucia negatywne, toteż zastąpiono go obcym słowem „kohabitacja”. Obyczajowość przedmałżeńska jest częścią zmian, jakie dokonują się we współczesnym społeczeństwie. Następuje deformacja narzeczeństwa poprzez wyraźne osłabienie kontroli społecznej i zanik wpływu kontroli rodziców, elastyczniejsze wzory wzajemnych stosunków międzyludzkich. Z obserwacji wynika, że w kohabitacji szybciej wkracza się w fazę kryzysu małżeńskiego. Wydaje się zatem, że kohabitacja to ucieczka przed odpowiedzialnością, a nie wzrost odpowiedzialności za drugą osobę i za dzieci.

Ks. dr Józef Młyński (wsR UKsw Warszawa) odniósł się do zagadnienia Rodzina fundamentem i bastionem trwałości społeczeństwa (narodu). Jego zdaniem rodzina jest żywym organizmem społecznym i dlatego należy się nad nią pochylić. Wspólnym podmiotem społeczeństwa i narodu jest człowiek, który do właściwego funkcjonowania w przestrzeni społecznej potrzebuje innych ludzi. W tym aspekcie jedynie rodzina jest źródłem społeczeństwa, w którym funkcjonuje jako jedna z najcenniejszych wartości. Dokonując analizy rodziny jako fundamentu trwałości społeczeństwa, należy zwrócić uwagę na te czynniki, w których wyraża się społeczne bytowanie rodziny w przestrzeni: miłości, życia, wychowania, tradycji, kultury, ekonomii, wspierania słabszych i starszych. W tym kontekście rodzina rozwijająca się w kierunku wartości jest nie tylko siłą napędową cywilizacji i ostoją człowieczeństwa, ale też bastionem zabezpieczającym los całej ludzkości i fundamentem społeczeństwa. Natomiast ks. dr hab. Marek Kluz (wTST UPJPII Kraków) w podjętej prelekcji pt. Odpowiedzialność za ojczyznę $w$ zjednoczonej Europie w ujęciu ks. prof. Józefa Bajdy wskazał, że istotnym elementem odpowiedzialności za ojczyznę jest kształtowanie postaw patriotycznych oraz właściwe wychowanie moralne. Nowe pokolenie często wzrasta w atmosferze duchowej pustki. W rodzinach, gdzie kształtowana jest postawa patriotyczna, widzi się ofiarność, wierność, rzetelne wypełnianie obowiązków, gościnność, pietyzm do tego, co polskie, a także pielęgnowanie katolickiego wychowania młodego pokolenia. Negatywną rolę w wychowaniu odgrywają tzw. subkultury młodzieżowe szerzące wzory szowinistyczne i neopogańskie. Dla księdza Bajdy ojczyzna jest terenem powołania i zadaniem dla każdego człowieka, którego powinnością jest miłować ją jak 
własną matkę. W kształtowaniu odpowiedzialności za ojczyznę powinny brać udział łącznie: rodzina, Kościół i szkoła.

Podsumowując, Międzynarodową konferencję naukową pt. Rodzina: miłość, małżeństwo, odpowiedzialność. Refleksja nad nauczaniem ks. prof. dr. hab. Jerzego Bajdy można udać za bardzo udaną. Przypomniano postać wybitnego naukowca i promotora rodziny oraz ukazano wartość rodziny we współczesnym świecie. $Z$ tej okazji przygotowano też wybór obszernych tekstów ks. prof. Jerzego Bajdy i zamieszczono w książce pt. Obrona i promocja rodziny. Zamyślenia Księdza Profesora Jerzego Bajdy, red. M. Kluz, J. Młyński, Sandomierz 2015, ss. 264. Oprócz podjętej tematyki rodziny w ujęciu interdyscyplinarnym konferencja stała się też okazją do wymiany myśli i inspirujących spotkań z różnymi naukowcami. Był to również czas umacniania więzi i przyjaźni z instytucjami spoza granicy: Niemiec, Austrii i Słowacji. 